\title{
Use of Alcohol among Young People: Evaluation of Factors that Affecting Its Use \\ Emirjona Kiçaj
}

Msc. in Nursing Science, Lectore, Faculty of Public Health, University of Vlore, Albania

Rudina Çerçizaj

Msc in Nursing Science, Lectore, Faculty of Public Health, University of Vlore, Albania

Ela Peto

Phd Candidate, Lectore, Faculty of Public Health, University of Vlore, Albania

Emiljana Coraj

Nurse specialist, Directorate of Public Health, Vlorë Albania ekicaj@yahoo.it

\section{Doi:10.5901/jesr.2015.v5n2p315}

\section{Abstract}

\begin{abstract}
The use of alcohol is common in many societies all over the the world. Alcohol harms not only the health, but also causes damage to the social character like: family or community violence and social isolation. Youth constitute one of the subgroups of the population who are more more risked from of alcohol use. The aim of the study was to assess the factors that affect the use of alcoholic beverages to young people presented under the effect of alcohol on the urgency of the Regional Hospital, Fier. This is a descriptive cros - sectional study relalized at Fier Hospital. In this study are included 70 youth who are submitted to the Regional Emergency Hospital, Fier to receive health care These young people have been under the influence of alcohol. Data for this study were taken through a questionnaire based on YRBHS questionare. 30\% of young people referred to had used for the first time an alcoholic drink at age 15-16 years, $65.7 \%$ of them were under the influence of alcoholic drink 2-3 times, $60 \%$ of young people indicated that they use alcoholic beverages in the company of their friends. $84.3 \%$ of young people show that they have used these alcoholic beverages in different bar, where their age did not constitute any problem. $78.5 \%$ of young people indicate that they use alcoholic beverages as a way to adapt to their society.
\end{abstract}

Keywords: youth, alcohol use, consequences of alcohol use.

\section{Introduction}

The use of alcohol is common in many societies all over the the world. Its consumption in significant doses, is a major risk to public health and safety [ Fuller E 208], [Newburn T 2001]], [Department of Health 2001], [Sheron N 2008]. Alcohol harms not only the health, but also causes damage in social life: family or community violence and social isolation [Hibell B 2003], [Jones L 2008], [Talbot S 2008], [Hughes S 2008]. In many cases, the damage associated with alcohol does not directly affect people who consume them, as in the case of road accidents [Currie C], [Velleman 2005]. On the other hand the damage caused by alcohol, contribute to inequalities in health among different population groups [Velleman 2005].

Youth constitute one of the subgroups of the population who are more more risked from of alcohol use.

\section{Purpose of the Study}

The purpose of this study was to assess the factors that affect the use of alcoholic beverages to young people presented under the effect of alcohol on the urgency of the Regional Hospital, Fier. 


\subsection{Specific objektives}

- To determine the initial age of use beginning of alcoholic beverages.

- To determine the amount of acohol among youth while they refer to have alcoholic drinks.

- To determine the knowledge that young people in terms of the effect that can bring the use of alcohol.

- Evaluate the reasons for the use of alcoholic beverages to young people

\subsection{Material and methods}

This is a descriptive cros - sectional study relalized at Fier Hospital. In this study are included 70 youth who are submitted to the Regional Emergency Hospital, Fier to receive health care These young people have been under the influence of alcohol. Data for this study were taken through a questionnaire based on YRBHS questionare. The questionnaire consisted on 3 parts:

The first group of questions provide information about personal data: age, sex, locations, place where they live, marital status of parents, education of parents, the use of alcohol from one parent.

The second group of questions provide information about the use of alcohol: the age when they used for the first time alcoholic drink, frequency of use of alcoholic beverages, quantity consumed, place of consumption

The third group of questions provide information about knowledge towards the consequences of the use of alcoholic beverages.

\section{Results}

Table 1. Tabular presentation of the distribution of young people according to socio demographic data.

\begin{tabular}{|c|c|c|}
\hline Variable & Number & $\%$ \\
\hline \multicolumn{3}{|l|}{ Age } \\
\hline 15 years & 7 & $10 \%$ \\
\hline 16 years & 19 & $27.1 \%$ \\
\hline 17 years & 19 & $27.1 \%$ \\
\hline 18 years & 25 & $35.8 \%$ \\
\hline \multicolumn{3}{|l|}{ Sex } \\
\hline Female & 3 & $4.3 \%$ \\
\hline Male & 67 & $95.7 \%$ \\
\hline \multicolumn{3}{|l|}{ Residence } \\
\hline Fier city & 67 & $95.7 \%$ \\
\hline Fier rural & 3 & $4.3 \%$ \\
\hline \multicolumn{3}{|l|}{ Civil status of parents } \\
\hline Living together & 64 & $91.4 \%$ \\
\hline Are divorced & 5 & $7.2 \%$ \\
\hline Widow & 1 & $1.4 \%$ \\
\hline \multicolumn{3}{|l|}{ Educational level of parents } \\
\hline Both with the university level & 5 & $7.1 \%$ \\
\hline University leve \& high school & 11 & $15.7 \%$ \\
\hline Both with high school & 45 & $64.3 \%$ \\
\hline High school \& Low levels of education & 8 & $11.5 \%$ \\
\hline Both with low level of education & 1 & $1.4 \%$ \\
\hline \multicolumn{3}{|l|}{ One of your parents is a user of alcohol } \\
\hline No, only on family events & 11 & $15.7 \%$ \\
\hline Rarely & 8 & $11.4 \%$ \\
\hline Yes, My father is frequent user of alcohol & 5 & $7.1 \%$ \\
\hline Neither of my parents do not use alcoholic drink & 46 & $65.8 \%$ \\
\hline
\end{tabular}

The dominant age of youth, who were present at the hospital to receive medical care after they were used alcoholic beverages was 18 years old. Only $4.3 \%$ of them was female. 95.7\% of young people actually living together with both parents. Only $7.1 \%$ of young people referred to one of the parents, namely father was a regular user of alcohol. $15.7 \%$ referred that they used only on family events. 
Table 2. Tabular presentation of the distribution of young people by the use of alcoholic drink

\begin{tabular}{|c|c|c|}
\hline Variables & Number & $\%$ \\
\hline \multicolumn{3}{|l|}{ How old were you when you've drunk for the first time alcoholic drinks? } \\
\hline 8 years even smaller & 0 & $0 \%$ \\
\hline $9-10$ years & 1 & $1.4 \%$ \\
\hline $11-12$ years & 5 & $7.1 \%$ \\
\hline $13-14$ years & 14 & $20 \%$ \\
\hline 15- 16 years & 21 & $30 \%$ \\
\hline $17-18$ years & 29 & $41.5 \%$ \\
\hline \multicolumn{3}{|c|}{ How many times you have been under the influence of alcoholic beverages } \\
\hline My first time & 11 & $15.7 \%$ \\
\hline $2-3$ times & 46 & $65.7 \%$ \\
\hline $4-5$ times & 7 & $10 \%$ \\
\hline $6-7$ times & 4 & $5.8 \%$ \\
\hline 8 - 9 times & 1 & $1.4 \%$ \\
\hline Over 10 times & 1 & $1.4 \%$ \\
\hline \multicolumn{3}{|l|}{ With who, you have been when you use alcoholic beverages } \\
\hline With my friends & 42 & $60 \%$ \\
\hline With my family & 21 & $30 \%$ \\
\hline Alone & 7 & $10 \%$ \\
\hline \multicolumn{3}{|c|}{$\begin{array}{l}\text { If you consume alcoholic drinks in the company of your friends, how many times has this happened in } \\
\text { the last } 30 \text { days? ( } 42 \text { youth) }\end{array}$} \\
\hline $1-2$ times & 21 & $50 \%$ \\
\hline $3-4$ times & 13 & $30.9 \%$ \\
\hline 5- 6 times & 6 & $14.3 \%$ \\
\hline $7-8$ times & 1 & $2.4 \%$ \\
\hline Over 9 times & 1 & $2.4 \%$ \\
\hline \multicolumn{3}{|l|}{ Your favorite drink } \\
\hline Beers & 57 & $81.4 \%$ \\
\hline Wine & 2 & $2.9 \%$ \\
\hline whiski & 5 & $7.1 \%$ \\
\hline Scotch & 4 & $5.7 \%$ \\
\hline Alcoholic cocktails & 2 & $2.9 \%$ \\
\hline \multicolumn{3}{|c|}{ During the last 30 days how have you provide alcohol? (you can choose more than one answer) } \\
\hline Bought in store & 6 & $8.6 \%$ \\
\hline I consumed in bars and restaurants & 59 & $84.3 \%$ \\
\hline someone else has bought for me & 0 & $0 \%$ \\
\hline My friends & 16 & $22.9 \%$ \\
\hline I've taken at my home & 13 & $18.6 \%$ \\
\hline \multicolumn{3}{|l|}{ How often have you been really drunk? } \\
\hline Never & 0 & $0 \%$ \\
\hline $1-2$ times & 64 & $91.4 \%$ \\
\hline $3-9$ times & 5 & $7.2 \%$ \\
\hline Over 10 times & 1 & $1.4 \%$ \\
\hline \multicolumn{3}{|c|}{ During the last 30 days, have you been refused to given alcohol because of your age? } \\
\hline Yes & 0 & $0 \%$ \\
\hline No, my age has not been a problem to take alcoholic drink & 70 & $100 \%$ \\
\hline \multicolumn{3}{|l|}{ The main reasons of alcohol use among youth } \\
\hline To be adjusted in society & 55 & $78.6 \%$ \\
\hline Family event & 5 & $7.1 \%$ \\
\hline Simply that I like to drink occasionally & 8 & $11.4 \%$ \\
\hline Now I am a regular user of alcohol & 2 & $2.9 \%$ \\
\hline
\end{tabular}

Even in Albania is noticed the beginning of the use of alcoholic beverages at very young age. $20 \%$ of youth with health problems after use of alcoholic beverages referred to have started drinking alcohol at age 13 years old. $65.7 \%$ of them referred to have been under the influence of the alcoholic drinks at least 2-3 times. We notice that most favorite moment of drinking alcoholic beverages by young people is when they are in the company of each other. As a favorite drink of the young people involved in this study is the beer (81.4\% of youth). According to the laws in the Republic of Albania, youth 
under age 18 years old can not offer alcoholic drinks. But we see that young people can find and consume easily alcoholic drink in bars, although in most cases they were under 18 years old.

The main reasons that young people refer about the use of alcoholic beverages is the easiest way to adapt with friends or simply to find new friends (78.6\%).

Table 3. Tabular presentation of the distribution of young people in terms of knowledge about the damage that causes the use of alcohol and source of receiving the information regarding the consequences of using the alcoholic

\begin{tabular}{l|cc|} 
Variables & Number & $\%$ \\
\hline The use of alcohol can put you at risk & & \\
IST & 2 & $2.9 \%$ \\
Intestinal damage & 5 & $7.1 \%$ \\
Auto accidents & 16 & $22.9 \%$ \\
To be involved in situations of violence & 5 & $7.1 \%$ \\
To damage the cardiovascular apparatus & 3 & $4.3 \%$ \\
To create dependency on the use of alcohol. & 17 & $24.3 \%$ \\
For damaged performance in school & 1 & $1.4 \%$ \\
To damage the nervous system & 12 & $17.1 \%$ \\
I don`t now & 34 & $48.6 \%$ \\
Information about alcoholic beverages and alcohol damage I have provided through & & \\
Books / schools & 26 & $37.1 \%$ \\
From my friends & 3 & $4.3 \%$ \\
Internet & 5 & $7.1 \%$ \\
I am not interested to know more & 36 & $51.5 \%$
\end{tabular}

Young people involved in the study, the use of alcoholic beverages is seen as a danger to create dependency on the use of these drinks and the opportunity to be involved in automobile accidents. But $48.6 \%$ of them do not have information about the damage that may induce the use of alcoholic beverages. This noticed in the following question where $51.5 \%$ of youth have expressed lack of interest to provide information regarding damages that may cause the use of alcohol

\section{Conclusion}

Youth in most cases do not have information about the risks that might bring the use of alcohol. The use of alcoholic beverages begins in a relatively small age $15-16$ years.

In terms of risk that may be posed by the use of alcoholic beverages, youth do not pay importance at exposure to STIs, intestinal damage, involvement in violence, damage to the device and damage the cardiovascular or performance at school.

Need to work much more at educational institutions to promote a healthier life to youth

\section{References}

Currie C, Gabhainn S, Godeau E, Roberts C, Smith R, Currie D, et al. Inequalities in young people's health: HBSC international report from the 2005/2006 Survey. Copenhagen: WHO Regional Office for Europe; 2008.

Department of Health. The Annual Report of the Chief Medical Officer: On the State of Public Health: Department of Health; 2001.

Fuller E, (Ed). Drug use, smoking and drinking among young people in England in 2007: National Centre for Social Research, National Foundation for Educational Research; 2008.

Hughes S, Bellis M, Hughes K, Tocque K, Morleo M, Hennessey M, et al. Risky drinking in North West school children and its consequences: A study of fifteen and sixteen year olds: Centre for Public Health, Liverpool John Moores University; 2008

Hibell B, Andersson B, Bjarnason T, Ahlström S, Balakireva O, Kokkevi A, et al. The ESPAD Report: Alcohol and Other Drug Use Among Students in 35 European Countries. Stockholm; 2003.

Jones L, Bellis M, Dedman D, Sumnall H, Tocque K. Alcohol-attributable fractions for England. Alcohol-attributable mortality and hospital admissions. Liverpool: Liverpool John Moores University and North-West Public Health Observatory; 2008.

Newburn T, Shiner M. Teenage Kicks? Young people and alcohol: a review of the literature. York Joseph Rowntree Foundation; 2001.

Sheron N, Olsen N, Gilmore I. An evidence-based alcohol policy. Gut. 2008;57:1341- 4.

Talbot S, Crabbe T. Binge drinking: young people's attitude and behaviour: Positive Futures, Crime Concern; 2008.

Velleman R, Templeton, LJ, Copello, AG. The role of the family in preventing and intervening with substance use and misuse: a comprehensive review of family interventions, with a focus on young people. Drug and Alcohol Review. 2005;24:93-109. 
